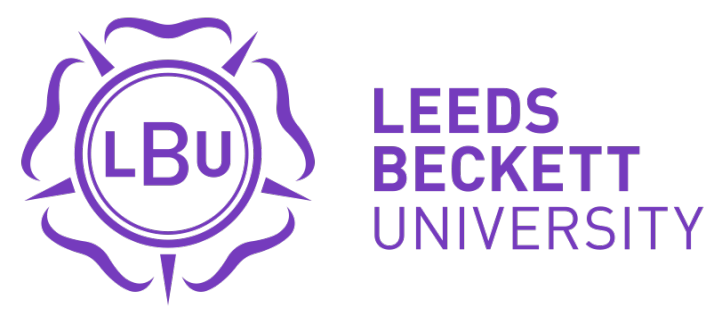

Citation:

Byrne, C (2020) What determines perceived graduate employability? Exploring the effects of personal characteristics, academic achievements and graduate skills in a survey experiment. Studies in Higher Education. pp. 1-18. ISSN 0307-5079 DOI: https://doi.org/10.1080/03075079.2020.1735329

Link to Leeds Beckett Repository record:

https://eprints.leedsbeckett.ac.uk/id/eprint/6605/

Document Version:

Article (Accepted Version)

This is an Accepted Manuscript of an article published by Taylor \& Francis in 'Studies in Higher Education' on 29th February 2020, available online: http://www.tandfonline.com/10.1080/03075079.2020.1735329

The aim of the Leeds Beckett Repository is to provide open access to our research, as required by funder policies and permitted by publishers and copyright law.

The Leeds Beckett repository holds a wide range of publications, each of which has been checked for copyright and the relevant embargo period has been applied by the Research Services team.

We operate on a standard take-down policy. If you are the author or publisher of an output and you would like it removed from the repository, please contact us and we will investigate on a case-by-case basis.

Each thesis in the repository has been cleared where necessary by the author for third party copyright. If you would like a thesis to be removed from the repository or believe there is an issue with copyright, please contact us on openaccess@leedsbeckett.ac.uk and we will investigate on a case-by-case basis. 


\title{
What determines perceived graduate employability? Exploring the effects of personal characteristics, academic achievements and graduate skills in a survey experiment
}

\author{
Dr. Christopher Byrne ${ }^{a *}$
}

${ }^{a}$ Leeds Beckett University, Leeds, UK

*Corresponding author. Email: christopher.byrne@leedsbeckett.ac.uk. ORCID:

https://orcid.org/0000-0003-2390-7126. Twitter: @C_M_Byrne.

Dr. Christopher Byrne is a Lecturer in Politics in the School of Social Sciences at Leeds Beckett University. He researches and teaches British politics and, as a Fellow of the Higher Education Academy, is also keenly interested in higher education pedagogy. 


\title{
What determines perceived graduate employability? Exploring the effects of personal characteristics, academic achievements and graduate skills in a survey experiment
}

\begin{abstract}
Governments have become increasingly concerned with improving the employability of university graduates in recent years, but most existing studies of what graduate employers look for are limited by their reliance on self-reported preferences. This study, which focuses on the UK context, aims to develop our knowledge of the determinants of perceived graduate employability by measuring the relative importance for employability of a range of personal characteristics, work-related skills and academic achievements using a survey experiment in which graduate employers rated fictitious recent graduates based on a series of short written profiles. The experiment found large effects in the ratings of graduates in response to cues referring to study abroad, work experience, age, degree type, disability, and ethnicity. This suggests that, while there are some things universities can do to improve the employability of their graduates, they are also to a large extent at the mercy of structured inequalities in society.
\end{abstract}

Keywords: employability; higher education; graduate skills; structured inequality; survey experiments

Over the past several decades the focus of debates surrounding UK higher education has shifted from the role of higher education in enabling individuals to better fulfil their role in society, towards the role of higher education in improving the 'employability' of university graduates in response to the emergence of the 'knowledge economy' and the consequent raising of the barrier for entry into the labour market (Tomlinson, 2007: 286). In that time, students have become more concerned with employability as a consequence of increases in tuition fees and the increased competitiveness of the graduate jobs market. Employers have become more vocal in their calls for a greater focus on employability due to a perceived lack of work-related skills and competencies 
among graduates - or because of what Tomlinson (2012: 425) refers to as a 'graduate over-supply' that employers find difficult to manage. Governments have also demanded action partly in response to employers' concerns, but also in order to achieve better 'bang for their buck' in a climate of straitened public finances and a productivity shortfall (Clarke, 2017).

However, there are significant gaps in the knowledge base upon which policy discussions in this area have proceeded. In short, we know little about the characteristics UK-based graduate recruiters and employers look for in job candidates and which ones they rate most highly, and many of the existing studies in this literature are limited by their reliance on the self-reported preferences of employers. In order to help rectify this situation and to enable improvements in the quality of both government higher education policy and universities' own initiatives to boost the employability of their graduates, this paper uses a survey experiment in which graduate recruiters and employers rated fictitious recent graduates based on a series of short biographies to determine the relative importance for employability of a range of personal characteristics, work-related skills and academic achievements. How the paper unfolds is, in the next section the literature on the factors determining employability within the UK labour market and beyond is considered. It is shown that, while there is some valuable scholarship pointing to the importance of educational attainment and, in particular, work experience for graduate employability, the existing literature is limited in that it neglects the UK case and focuses on too narrow a range of factors that feed into employability. In particular, there are no studies systematically comparing the effects of the most important personal characteristics, work-related skills and academic achievements in the UK context. Following that, in the methodology section there is an overview of the survey experiment used, including the specific graduate characteristics 
tested, the means by which they were tested, and on whom they were tested. Then, in the second half of the paper there is an overview of the key findings of the survey experiment, with the most important one being that perceived employability is affected by, in order of magnitude of effect size, age, degree type, disability, study abroad, work experience, ethnicity, extra-curricular activities, sex and degree class. The article concludes with a discussion of the significance of these findings for higher education institutions' employability strategies and current government higher education policymaking.

\section{Possession, position, process: perspectives on graduate employability}

A useful way of beginning to explore the literature on graduate employability is to consider the divide between 'possession', 'position' and 'process' accounts of graduate employability, emphasised by authors such as Hinchliffe and Jolly (2011), Holmes (2001), Holmes (2013), Jackson (2016), Okay-Sommerville and Scholarios (2017) and Clarke (2017). These three terms are preferred by Holmes (2013) to refer to approaches that focus on the skills and attributes graduates possess, the role of higher education in reinforcing social positioning and status, and the extent to which a 'graduate identity' mediates the university-to-work transition, respectively. The first approach was notably the approach of the landmark 1997 Dearing Report into the future of UK higher education, which identified four 'key skills' graduates should possess ('communication skills,' 'numeracy,' 'the use of information technology' and 'learning how to learn') in order to safeguard that future. Meanwhile, academic analyses exhibiting this approach would include Teijeiro et al (2013), Hinchliffe and Jolly (2011) and Jackson (2016), and a notable recent analysis from a professional body is the Chartered Management Institute's survey of managers and business and management students, which found that the most in-demand skills among first-time managers are the ability to take 
responsibility, people management skills, honesty and ethical awareness, problem solving and teamworking (CMI, 2018: 6).

According to Holmes (2013: 546), one problem with this approach relates to the way in which the concept of 'graduate skills' has been operationalised: there is a general lack of precision in the way terms referring to specific graduate skills and attributes are used, in policymaking circles, in higher education and by employers (for example, institutions might seek to improve the 'communication skills' of their students, but might mean different things by that term). Another problem relates to the fact that most investigations of graduate skills and attributes are based on surveys of employers, 'stakeholders' or academic experts, which is problematic because of the possibility of these latter misidentifying the real determinants of graduate employability, thereby limiting the validity of such studies. A third problem with this approach is that it provides no way of explaining differences in employment outcomes between graduates with different personal characteristics (for example, along the lines of social class or ethnicity).

The second approach — the 'positional' approach — is welcome because it does have something to say about differential outcomes based on personal characteristics, but its central problem is that it overlooks the difference the presentation of an appropriate graduate identity can have on employment outcomes (Holmes, 2013: 548). For this reason, Holmes argues the 'process' perspective is superior, with its acknowledgement that the transition from higher education to the world of work is an 'identity project', with the resulting identity being non-essential, constructed and relational:

to be successful an individual must become a graduate, not just in the formal sense of being awarded a degree but in socially and biographically significant terms, 
whereby they act in ways that lead others to ascribe to them the identity of being a person worthy of being employed (Holmes, 2013: 549).

From this perspective, graduate skills and attributes are still important: they are 'elements in the discursive repertoire' of the graduate, but the degree to which the graduate's identity is accepted by a prospective employer is also dependent upon their ability to provide relevant credentials (chiefly, a degree certificate) and to be able to speak about those skills both competently and confidently (Holmes, 2013: 550). The 'process' perspective is also superior to the positional perspective because it avoids falling prey to the 'council of despair' problem that necessarily flows from the latter.

In a variation on this theme, Clarke (2017) theorises graduate employability as determined by a combination of human capital (comprising a mixture of occupationspecific expertise and transferable or 'higher order thinking' skills such as problemsolving and teamworking), social capital (referring to social class, embeddedness in networks, type of university attended, type of degree obtained, and degree classification), individual behaviours (specifically, career self-management), individual attributes (referring to dispositions such as adaptability and flexibility that feed into career self-management and which are highly valued by potential employers) and, finally, labour market variables (prevailing macroeconomic conditions such as longterm business confidence, the level and nature of labour demand in the economy, and the geographical concentration of job opportunities). Clearly, the most significant overlap here with Holmes' thesis is in relation to 'career self-management', with Clarke (2017: 4) reformulating 'graduate identity' as 'graduateness', which is a presentation to employment gatekeepers designed to distinguish the individual graduate from both nongraduates and fellow graduates, centred around an image of the individual graduate as a 
career-seeker with (or capable of acquiring) the human and social capital demanded by employers.

Okay-Sommerville and Scholarios (2017) attempted to move this discussion in a more empirical direction with their study based on a survey of approximately $300 \mathrm{UK}$ graduates, which uncovered evidence to support the process and (to a slightly lesser extent) possession views of graduate employability. Specifically, networking was found to increase the likelihood of receiving job offers and being in employment, while ‘environmental exploration' (for example, attending careers fairs) and guidance-seeking were found to enhance employment quality and perceived external employability. Additionally, having a non-professional degree subject led to poorer employment quality and perceived external employability, while having graduated with a lower degree classification led to poorer employment quality and perceived internal employability. However, these findings can be questioned on the grounds that the authors' conflation of a 'process' approach to employability with career selfmanagement is mistaken, given the essentially intersubjective nature of forming an effective graduate identity. In other words, a student can engage in career selfmanagement practices such as attending careers fairs and yet still lack the interpersonal skills necessary to appear employable in a job interview setting.

'Position' and 'possession' explanations have been the focus of most of the rest of the literature. Of the existing 'position'- and 'possession'-focused studies, three in particular stand out as particularly useful. These are the analyses of Eriksson et al (2016), Humburg and van der Velden (2015), and Kinash et al (2016). Eriksson et al (2016) looked at a range of 'position' and 'possession' factors, which were (in relation to the former) age, gender, weight, ethnicity, religion and social class, and (in relation to the latter) prior educational attainment, work experience, frequency and intensity of 
sickness absence, and wage demands. They found in their stated choice experiment involving approximately 400 Swedish employers that, at the shortlisting stage, an applicant being in the highest quartile of educational attainment and having at least five years of work experience improved their chances of success, while being over 55 years old diminished those chances. Meanwhile, at the hiring stage, and testing a wider array of characteristics, they found that a candidate being frequently absent from work, especially for long durations, being overweight or obese, being Muslim, being Jewish, being an immigrant (from Africa, the Middle East or South America), or having two or more children diminished their chances of being hired. Again, gender was found to have no effect, but it is possible that this is a product of the particular, gender equalityfocused political culture of Sweden (see Social Watch, 2012) or the design of the stated choice experiment, which increased scope for reactivity due to the somewhat artificial nature of the choice participants were asked to make.

Humburg and van der Velden's (2015) study, which conducted discrete choice experiments with approximately 900 employers across nine European countries, for the most part validates Eriksson et al's study, finding that a candidate being at least above average in prior educational attainment and possessing relevant work experience led to a statistically significant improvement in their perceived employability. However, they also tested the effect of the type of degree possessed by an applicant (that is, a Bachelor's, Master's or Doctorate), their degree subject (in terms of the match between degree subject and job tasks), their university's prestige, and their having studied abroad. They found that possessing a Master's over a Bachelor's degree did not improve a candidate's perceived employability (in contrast to this study, which found that possessing a Master's did enhance employability), and that possessing a Doctorate actually diminished perceived employability (although it should be noted this was in the 
context of a hypothetical generic graduate-level job which it would be unusual for someone graduating with a Doctorate to apply for), and that a close match between field of study and job tasks, having gone to a prestigious university, and having studied abroad all improved candidates' perceived employability. However, as with Eriksson et al's study, the artificial nature of the choice presented to participants — with them being asked to judge hypothetical candidates based on lists of facts about them — arguably limits the validity of the findings due to a greater awareness on their part that they are taking part in an experiment, and the increased scope for reactivity and social desirability bias that flows therefrom. In terms of differences between countries, these were largely underexplored in the study and in many cases the effects observed were not statistically significant. However, a comparative analysis of perceptions of the value of a Master's degree did reveal that at the aggregate level in the UK a candidate with a Master's degree is actually perceived as less employable than one without, with the reverse being true in some other European countries (namely, Germany and Poland), although the effect of a Master's degree did not quite meet the threshold for statistical significance in the UK case (Humburg and van der Velden, 2015: 32). Similarly, UK employers perceived students who had obtained a degree abroad as significantly less employable, whereas in every other European country tested except Sweden (in relation to which the difference was not statistically significant) the effect was the opposite, which suggests that the UK labour market is something of a 'special case' in need of further detailed analysis.

Taking a more direct approach, Kinash et al (2016) identified twelve distinct higher education employment strategies based on their own review of the graduate employability literature and asked a large number of Australian students, graduates, educators and employers which they were most supportive of. In keeping with both 
Humberg and van der Velden (2015) and Eriksson et al (2016), they found widespread support for 'work experience' as a means of improving graduate employability, with this attribute being ranked number one among students, graduates and employers (although not higher education professionals, who rated things such as career advice and extra-curricular activities more highly). Interestingly, and perhaps counter-intuitively, they also found that part-time work was only highly valued by students and graduates, and not higher education professionals and employers. This perhaps suggests a misapprehension on the part of the former, that any kind of work enhances employability, despite higher education professionals and employers being cognisant that work undertaken alongside a degree not aligned with graduates' intended future careers can over-burden students, damage their educational attainment, and take time away from other, more useful employability activities (Kinash et al, 2016: 959; see also Callender, 2008 on the potentially detrimental effects of term-time employment and Orrell, 2004 on the need for work experience to be meaningful, relevant and pitched at an appropriate level in order to be useful). The added value of relevant work experience for graduate employability likely stems from its ability to imbue current students with a stock of occupation-specific knowledge that a degree alone cannot match, and the fact that it enables students to begin to fashion an appropriate 'professional identity' (which is crucial given the intersubjective nature of what constitutes an employable graduate) prior to actually entering the world of work (Jackson, 2016: 1314).

Despite the findings of these three studies suggesting that relevant work experience is highly beneficial for graduate employability, it should be noted that there are studies that cast doubt on this notion. For example, Wilton (2012; see also Wilton, 2011) argues that there is no clear link between work placements and graduate employability, finding in his study - comprising interviews with UK-based business 
and management graduates and statistical analysis of historical survey data - that while work placement graduates typically reported having better employability skills, the differences were minimal, and in some areas (for example, 'creativity') non-work placement graduates actually reported better employability skills. Furthermore, nonwork placement graduates were more likely than work placement graduates to be employed in managerial and associate professional occupations four years after graduation, and work placement graduates were more likely to be in non-graduate jobs (although, contradictorily, work placement graduates were found to have higher salaries). These findings can potentially be explained by reference to the fact that work placements are more common at less well-established, less prestigious universities (which means that although they might be beneficial, the benefits are outweighed by the benefits of graduating from an elite university), and the relevance of these findings is potentially limited by the fact that the study looked only at business and management graduates and used survey data collected as long ago as 1999. Nevertheless, in the above-mentioned study undertaken by Okay-Sommerville and Scholarios (2015), one of the characteristics tested, but found to have no statistically significant effect on employment quality or perceived employability was work experience.

This overview depicts a body of literature on employability that provides some valuable insights, but not the last word on what makes graduates employable. Some important possible determinants of graduate employability are either completely overlooked (as in the case of the effects of being disabled) or dealt with inadequately (as in the case of ethnicity). It is also true that our knowledge of the range of personal characteristics, work-related skills and academic achievements affecting perceived employability is the product of a wide array of methodological approaches, some of which are problematic, either because of reliance on self-reporting or experimental 
settings that are likely to have been experienced by participants as highly artificial. This is possibly why different authors have come to wildly different conclusions as to the effects of factors such as work experience, gender and degree type on graduate employability. Furthermore, although the existing literature clearly suggests that the determinants of perceived employability vary on a cross-national basis, the UK case has been somewhat neglected.

The purpose of this study is to fill in some of these gaps in the literature by focusing specifically on the range of personal characteristics, work-related skills and academic achievements UK-based graduate recruiters and employers look for in job candidates. It thereby enhances the knowledge base upon which government policymaking and the employability strategies of higher education institutions proceed, using a clear and coherent methodological approach premised on a survey experiment that minimises scope for reactivity on the part of research participants. To that end, it made sense to include a range of 'possession' and 'position' characteristics for testing. Both relevant work experience and non-relevant part-time work seemed exigent, given the contradictory accounts outlined above. Study abroad and extra-curricular activities were also included, on the grounds that there were very few studies of these characteristics with a specific UK focus (as mentioned above, Humburg and van der Velden did compare the UK experience of study abroad with several other European countries, but their findings were inconclusive and only considered study abroad for the duration of a degree, as opposed to part of a degree). Degree type and classification were also included for much the same reason, and in order to establish the relative importance of academic achievements in comparison to personal characteristics and work-related skills. In the case of gender, ethnicity and disability, a recent Department for Business, Innovation and Skills report (BIS, 2015: 16) found that these were 
important foci of employers' diversity and social inclusion agendas, and although age, sex and ethnicity have been the subject of academic inquiry the only empirical study to date (Eriksson, 2016) focused exclusively on Sweden. An additional important reason to study the effects of disability on perceived employability was the increased proportion of students with disabilities attending UK higher education institutions over recent years (Richardson, 2015).

Despite there being evidence, referred to above (see Humburg and van der Velden, 2015 and Okay-Sommerville and Scholarios, 2017), that degree subject affects both perceived employability and actual employment outcomes, this characteristic was not tested for three reasons: firstly, because holding degree subject constant would make it easier to measure the effect of other characteristics; secondly, because the research method used, which is justified for reasons outlined in detail below, is ill-equipped to measure the effect of independent variables with very many categories and is, conversely, better equipped to handle dichotomous variables (such as sex or the possession of foreign language skills); and, thirdly, because to date there has been little research specifically on the employability of social science graduates, which this study was partly designed to rectify.

\section{Methodology}

In this section the rationale behind the use of a survey experiment to measure perceived employability, and how the process worked, is set out, before the specific characteristics tested, composition of the sample and limitations of the research design are considered. The main benefit of an experimental approach to examining graduate characteristics is that it allows 'confounding effects' to be separated out while also avoiding the potential for social desirability bias, which arises when survey respondents give the answer they believe will paint them or their organisation in the most favourable light possible given 
prevailing social norms and the expectations of survey administrators (Campbell and Cowley, 2014a: 746). In theory it should not be possible for respondents to identify the socially desirable answer in a well-designed survey experiment, because the choice they think they are being asked to make — in this case, between two fictional graduate profiles - is not the meaningful one, with the research findings instead stemming from patterns observed at the aggregate level when a single characteristic in one graduate profile is altered for part of the sample. In practical terms how this survey experiment worked is respondents were asked to compare fictional politics and international relations graduates from a single leading UK university (the University of Exeter) in a series of pairs, based on short candidate profiles (all of which are contained in the appendix) and accompanying photographs, and to select which out of each pair they deemed to be the most employable. The first characteristic tested in this way was gender and, as such, one half of the sample, made up of all of the employers and graduate recruiters in the University of Exeter's Career Zone's database, was shown the following two profiles:

My name is Saina Nehwal. I'm 21 and from Plymouth. I'll graduate this summer with a BA in Politics. I think I'm employable because my degree has given me good research skills and the ability to articulate myself orally and in writing, and because I have quite a bit of work experience. I've worked in a coffee shop in the Student's Guild for the past two years while at university, and done lots of casual work during the summer holidays.

My name is Jack Jones. I'm 22 years old and originally from Leeds. I'm doing a BA in International Relations. I think I'm employable because I'm on course to get a 2.1, and because I'm active in the Student's Guild. I'm proud to have helped found the Students' Action for Refugees (STAR) Society in my second year at university, which I think shows good organisational and teamworking skills. 
The second half of the sample was then shown the same two profiles, but with the name 'Jack Jones' in the second profile changed to 'Gemma Jones', and the accompanying photograph changed from one of a male to a female. The photographs used were of actual University of Exeter students (obtained under a Creative Commons license), but all other aspects of the graduate profiles were fictional, even if they were designed to be as realistic as possible and were written as if spoken by a typical recent graduate so as to minimise scope for reactivity.

By then analysing the data to see if the second half of the sample were more likely to favour the second candidate (in their case, 'Gemma Jones'), any swing towards or away from this candidate could be attributed to the effects of gender stereotypes. Statistical significance was established using chi-square tests, which were deemed to be most suitable due to the randomised nature of the application of the control in the survey experiment (obviating the need for regression analysis using artificial control in the form of independent variables) and the fact that the dependent variable in this case was nominal (hence the unsuitability of ANOVA) (Campbell and Cowley, 2014b). Altogether there were nine pairs of fictional graduates, testing the personal characteristics of gender, age, disability and ethnicity, the work-related skills linked to work placements, study abroad and extra-curricular activities, and academic achievements in the form of degree type and degree classification. These characteristics were selected for testing on the grounds that they were either largely overlooked within the literature — as in the case of, for example, disability and ethnicity — or did feature in the literature, but were the subject of some controversy. This was notably the case in relation to work experience, where authors such as Humburg and van der Velden (2015) and Eriksson et al (2016) found that the employers they surveyed valued work experience highly as it indicated possession of occupation-specific human capital (see 
also BIS, 2015: 15), but authors such as Wilton (2011) and Okay-Scholarios (2017) found a much muddier picture. In a more general sense, looking at a mixture of personal characteristics, work-related skills and academic achievements would help settle the question, discussed above, of whether 'position' or 'possession' is more important in considerations of graduate employability. The specific personal characteristics selected for testing were largely derived from well-established critical realist accounts of structured inequality in British society put forwards by Marsh (2008) and Marsh et al (2003), with the notable exception of social class, which it would be very difficult to test for given the complex and constantly evolving nature of social class (see Savage et al, 2013) and the difficulty associated with inserting effective markers of social class into a 'low information' research design such as this.

Most of the above characteristics were 'A/B tested', in that the sample was split just two ways, but some were also 'C tested' in that the second half of the sample was split again, in order to allow for another variation of the characteristic being tested. This was the case in relation to work placements (where the first variation was to include a work placement integrated into the candidate's degree, and the second was to include part-time work alongside the degree, in order to see if the former provides any 'added value'), ethnicity (in order to be able to examine the effects of varying with Black and Asian ethnicities), degree type (where the intention was to measure the effects of both a Master's degree and a doctorate), and study abroad (where one variation was study abroad in another English-speaking country and the other was study abroad in a Frenchspeaking country, in order to see if study abroad was primarily valued by employers for its ability to develop foreign language skills). In order to further minimise scope for social desirability bias, the order in which the changed characteristic was presented was varied randomly (that is, sometimes it was in the first half of the sample shown the 
profile with the changed characteristic, and at other times it was the second). A pilot study comprising ten per cent of the intended sample was conducted in order to flag up and help address certain research design issues. Specifically, it was important to ensure that the initial profiles shown to the graduate employers and recruiters were perceived to be fairly evenly-matched, because otherwise it might not have been possible to accurately measure the swing in perceived employability towards or away from a candidate after the profiles were altered (an increase in favourability from 90 to 100 per cent is only superficially the same as an increase in favourability from 50 to 60 per cent).

The sample as a whole was made up of all of the employers and graduate recruiters in a database belonging to the University of Exeter's employability service, Career Zone. This included some 3484 UK-based graduate employers and recruiters that work with the university on an ongoing basis for various reasons relating to graduate recruitment, such as to advertise graduate vacancies. Respondents were recruited via an email invitation containing basic information about the project and a link to the survey website (Google Forms), and a follow-up email invitation two weeks later. Respondents were able to take part in the survey by clicking through to the survey website. That is where the data was automatically collated, which was then exported to IBM SPSS for statistical analysis. The survey received 57 responses overall, to produce a somewhat disappointing response rate of 1.6 percent. The low response rate was likely the result of a combination of factors. The design of the survey may have been offputting for some (the survey experiment required each pair of candidates to be relatively evenly matched, and being confronted with a series of nine 'close calls' may have frustrated some respondents). There was also anecdotal evidence that some employers blocked the survey website (Google Forms) using spam-blocking tools, which left some 
potential respondents simply unable to participate. Spam-blocking tools have developed in tandem with the fast growth of unsolicited emails and it tends to be the case that widely-used survey websites, such as the one used in this study, are more easily identified and blocked (Couper, 2000; Couper et al, 2007). There is also evidence that the topic of a survey influences response rates, with more salient topics tending to produce a higher response rate (Groves, Cialdini and Couper, 1992; Dillman, 2007: 15; Cook et al, 2000; Sheehan, 2001; Yammarino et al, 1991). Given the somewhat obscure nature of this survey experiment, it is possible that perceptions of low salience were also a factor in the low response rate.

A low response rate does not necessarily imply an unrepresentative sample (Meterko et al, 2015; Groves, 2006), and in any case is par for the course in online surveys (Manfreda, Bosnjak, \& Berzelak et al., 2008), but it does raise the possibility of sampling bias. Thus, results will need to be replicated at other UK universities and internationally. However, comparing the profile of the survey respondents to the target population of UK graduate employers in terms of business size, a Chi-square test showed that the former was broadly representative of the latter, with there being no statistically significant difference between the two $\left(x_{1}^{2}=2.209, p=.331\right)$. A number of balance tests were also conducted in order to ensure that differences in candidate preferences between the groups were not the product of differences in the composition of those groups. To that end, an ANOVA test of the age of respondents across the subgroups showed that there was no statistically significant difference in the mean age of respondents, and chi-square tests on sex, ethnicity and business size showed that differences between the groups in these respects were neither large nor statistically significant. 
In terms of limitations of the study, the most obvious one is that it was limited to politics and international relations students at a single UK university, although this was arguably justified by the strong bias of the survey experiment method towards dichotomous variables and the consequent difficulty of accommodating the wide range of degree subjects and types of universities in UK higher education. The experiment also did not test other possible determinants of perceived graduate employability linked to the concept of 'graduate identity' (Holmes, 2001; Hinchliffe and Jolly, 2011).

Although it is reasonable to suggest that personal qualities such as confidence, selfefficacy, self-reflection, adaptability, entrepreneurialism and, most importantly of all, the ability to construct a graduate identity that affirms an individual's suitability for a particular job role all enhance employability, the primary focus here is on the tangible personal characteristics, achievements and skills. These are the raw material out of which graduate identities are constructed, and which in any case are more amenable to testing using a survey experiment of this kind.

The results presented below may also have been compromised by the use of photographs in the fictional candidate profiles, because there is research that suggests perceived employability may be affected by attractiveness (Eriksson et al, 2016) and dress (Cutts, Hooley and Yates, 2015) and, as was explained above, some variations in candidate profiles necessitated changing the photographs used, which may have swayed some respondents. However, the experiment proceeded with photographs because on balance their contribution towards the naturalness of the experiment was thought to outweigh their potential to factor as intervening variables — and in any case it would have been virtually impossible to properly test the effects of certain characteristics, such as ethnicity, without using photographs. 


\section{Results and discussion}

As shown in Table 1, all of the graduate characteristics tested produced some kind of statistically significant swing away from the baseline profile, although with varying magnitudes and not always in the direction expected. The single largest increase in candidate preferability (at 44 per cent) was attributable to an increase in the candidate's age from 21 to 42 (and changing the photograph accompanying the graduate profile in question). This was unexpected because it runs somewhat counter to Eriksson et al's (2016) study, which found that the characteristic most detrimental to a job candidate's chances of receiving a 'callback' after submission of a CV was being over 55 years of age. That said, the authors also found that being between 30 and 55 years old slightly benefited job candidates at the shortlisting stage, perhaps indicating that employers perceive a 'sweet spot' in terms of the ideal candidate having some maturity and realworld experience, but not being too close to the end of their career to be worth investing in. The most recent DLHE surveys (HESA, 2017; HESA, 2016) do not seem to back this up at first glance, given that they show unemployment being higher among mature graduates (even if by no more than 2 per cent), but this factors in neither the diminished job prospects (or preference for retirement) of over-55s nor the quality of jobs, and it would be interesting to investigate if mature students have higher salaries than younger ones after graduation. Jackson's (2014) study of labour market outcomes for Australian graduates did find that more mature graduates did have a labour market advantage.

[Table 1 near here]

The second largest increase in candidate preferability was another curveball: degree type. The survey experiment found a statistically significant swing of 35 per cent when the candidate's degree type was changed from a BA International relations to an 
MA in the same subject, indicating that most employers value postgraduate qualifications highly, despite previous research having cast doubt on their value for employability. Humburg and van der Velden (2015) found that possessing a doctorate was a significant hindrance to finding employment (with employers reporting views that these candidates tend to be too scholarly or 'theoretical' for most graduate-level jobs) and that possessing a Master's degree was of negligible benefit. Meanwhile, the third largest increase in candidate preferability perhaps indicates the encroachment of social desirability bias, because it seemed to indicate that disability is a positive thing from an employer's perspective: giving the candidate a disability (and changing the accompanying profile photograph accordingly) led to a 26-point increase in preferability. If this is not indicative of a social desirability bias, it can perhaps be explained either by a desire to diversify workplaces (the unemployment rate for disabled people is 9 per cent compared to 3.8 per cent for the rest of the population) (Brown and Powell, 2015) or some other intrinsic value often possessed by employees with disabilities.

The next three largest effect sizes were all linked to the work-related skills mentioned above: a candidate having studied abroad accounted for a 23.5-point increase in preferability; a candidate having done a work placement as part of their degree accounted for a 17.7-point increase in preferability; and a candidate having engaged in extra-curricular activities while studying led to a 16.3-point increase in preferability. It is largely unsurprising that possession of these characteristics enhanced graduate employability, given previous research outlined above, although the lack of a larger effect for having done a work placement is curious. However, there are some important nuances in the data. In the case of study abroad, while studying at a partner institution in a non-English speaking country (in this case, France) was highly beneficial, studying at 
a partner institution in an English-speaking country actually proved detrimental (leading to a statistically significant 14.9 -point decrease in candidate preferability), perhaps indicating the real value for employers of study abroad lies in its ability to improve the foreign language skills of graduates, rather than the 'intercultural skills' identified by Jones (2013). That said, it is important to caution that some of the swing could be attributable to either a perceived difference in the quality of higher education in the two countries tested (France and the US) and/or to a perceived difference in the quality of the specific universities tested (Université de Strasbourg and Colorado State University) — although the universities were selected on the grounds that they occupied similar positions in university league tables (both institutions were ranked in the 351-400 range of the politics and international studies branch of the Times Higher Education World University Rankings 2018).

Meanwhile, although having done a work placement integrated into a degree course was highly beneficial for perceived graduate employability, having just had work experience — that is, a part-time job undertaken alongside a degree course — was highly detrimental. This is in keeping with Weiss and Klein's (2014) findings in relation to the German labour market that graduates do not benefit from work experience that is unrelated to field of study, and perhaps indicates that either graduate recruiters and employers perceive part-time work alongside a degree to lead to lower education attainment. Alternatively, this characteristic may have acted as a marker of social class, given that students from lower socioeconomic backgrounds tend to undertake paid work during term time (BIS, 2013). It is noteworthy in this relation that the two most prestigious British universities - Oxford and Cambridge — both explicitly disallow students from taking on paid work during their studies (Gil, 2014). The fact that adding engagement in extra-curricular activities to a candidate's profile resulted in almost as 
large an increase in preferability as a work placement and study abroad may be somewhat surprising, but is less so when considered in light of Hinchliffe and Jolly's (2011) employer survey, which found that particular values (diversity and cultural awareness, environmental awareness, entrepreneurship), skills (especially interpersonal skills) and appropriate forms of social engagement (a candidate having 'fully exploited the university experience') were crucial inputs into an effective graduate identity — all of which can be developed through extra-curricular activities.

The sex of the candidate produced the next largest effect size, with changing the candidate's sex from male to female resulting in a 15.2 per cent increase in candidate preferability. This can be attributed, again, to the possible incursion of social desirability bias, which is a definite possibility given the discrepancy in the median gross hourly earnings of men and women, including among younger age cohorts (Costa Dias et al, 2018), because if employers really perceived women to be more employable then why would this pay gap still exist? The final characteristic to produce an increase in candidate preferability was degree class, with possession of a first-class degree as opposed to an upper second-class degree improving perceived employability by some 14.9 points. This is a substantial effect, but also a smaller one than, for example, engaging in extra-curricular activities, which might indicate a more well-rounded and sociable graduate.

This leaves ethnicity as the final characteristic to have an effect on candidate preferability, but in this case, changing the ethnicity of the candidate from white British to black British resulted in a marked decrease in candidate preferability, of 17.7 per cent, which is equivalent to the effect of the candidate having done a work placement as part of their degree, but in the opposite direction. In other words, this research shows that a black British candidate for a graduate job needs to have undertaken a work 
placement integrated into their degree just to be perceived as equally employable with a white British candidate having not done a work placement. It is difficult to explain this outcome as due to anything other than racial discrimination on the part of the graduate recruiters and employers who took part in the survey experiment although, again, it should be noted that changing this characteristic also required a change of profile photograph, which could potentially account for some of the swing. Interestingly, when the candidate's ethnicity was changed to British Asian (and, additionally, implying that the candidate was a Muslim by using a picture of a woman in a headscarf) there was a reduction in preferability of some 8.7 percent — so roughly half that of the effect of Black British ethnicity, but still large - although the difference in this case was not statistically significant. In terms of the preferences of different kinds of graduate recruiters and employers, along the lines of age, sex, ethnicity and company size, there were no statistically significant findings — quite possibly due to the small sample size once the survey had been split three ways and then crosstabulated according to these dimensions — with one exception: women respondents were found to react more positively to study abroad than their male counterparts, at least when it came to study in a non-English speaking country, with 82 percent of women preferring the candidate with this experience compared to just 33 per cent of men $\left(x_{1}^{2}=3.996, p=.046\right)$. This presents interesting possibilities for further study.

\section{Conclusion}

As Frankham (2017: 629) notes, working out what employers want is fraught with difficulty given the heterogeneity of different kinds of employers and the extent to which much of the most useful training in industry is of the 'on the job' kind. There is already a vast body of research showing that graduate employability can be enhanced by giving students the tools to develop appropriate graduate identities, such as developing 
their entrepreneurial skills (Kucel et al, 2016; Bell, 2016), their abilities of selfreflection (Dacre Pool and Qualter, 2012), their adaptability (Wright and Frigerio, 2015; Lin, 2015), and their confidence and self-belief (Qenani et al, 2014). However, the main contribution to knowledge of this study is that perceived employability is also affected by a range of personal characteristics, academic achievements and the ability to demonstrate particular graduate skills. In particular, in order of magnitude of effect size, age, degree type, disability, study abroad, work experience, ethnicity, extra-curricular activities, sex and degree class were all found to have a sizeable and statistically significant effect on perceived employability. This means that if universities want to improve the employability of their graduates they can attempt to do this by expanding the range of extra-curricular activities, work placements and study abroad opportunities available to students. Universities may also boost employability by recruiting more mature and returning students, by prioritising recruitment on Master's programmes, and by discouraging part-time work during term. However, what this study also suggests is that some determinants of graduate employability are beyond the control of individual universities, because it would clearly not be acceptable (not to mention illegal under the Equality Act 2010) for universities to seek to boost their employability performance by recruiting more students with gender, ethnicity and disability profiles shown to enhance perceived graduate employability. On the contrary, it is deeply concerning that ethnicity in particular continues to be a factor in the perceived employability of graduates, despite the best efforts of universities in recent years to widen participation.

\section{Acknowledgements}

I would like to thank Dr. Katie Dhingra and the two anonymous referees for their useful suggestions and comments on earlier drafts of this article. 


\section{Disclosure statement}

No potential conflict of interest was reported by the author.

\section{Bibliography}

Brown, Jennifer, and Andy Powell. 2018. "People with Disabilities in Employment," January.

https://researchbriefings.parliament.uk/ResearchBriefing/Summary/CBP-7540.

Callender, Claire. 2008. "The Impact of Term-time Employment on Higher Education Students' Academic Attainment and Achievement.” Journal of Education Policy 23 (4): 359-377. doi:10.1080/02680930801924490.

Campbell, Rosie, and Philip Cowley. 2014a. 'What Voters Want: Reactions to Candidate Characteristics in a Survey Experiment'. Political Studies 62 (4): 745-765. doi:10.1111/1467-9248.12048.

Campbell, Rosie, and Philip Cowley. 2014b. 'Rich Man, Poor Man, Politician Man: Wealth Effects in a Candidate Biography Survey Experiment'. The British Journal of Politics and International Relations 16 (1): 56-74. doi:10.1111/1467856X.12002.

Chartered Management Institute (2018) 21st Century Leaders: Building Employability through Higher Education. [Online]. Available from: <https://www.managers.org.uk/ /media/Files/Reports/insights/research/21st_Ce ntury_Leaders_CMI_Feb2018.pdf>.

Clarke, Marilyn. 2017. "Rethinking Graduate Employability: The Role of Capital, Individual Attributes and Context." Studies in Higher Education, February, 115. doi:10.1080/03075079.2017.1294152.

Cook, Colleen, Fred Heath, and Russel L. Thompson. 2016. 'A Meta-Analysis of Response Rates in Web- or Internet-Based Surveys': Educational and Psychological Measurement, July. doi:10.1177/00131640021970934.

Costa Dias, Monica, Robert Joyce, and Francesca Parodi. 2018. Wage Progression and the Gender Wage Gap: The Causal Impact of Hours of Work. doi:10.1920/BN.IFS.2018.BN0223. 
Couper, Mick P. 2000. 'Web Surveys: A Review of Issues and Approaches'. Public Opinion Quarterly 64 (4): 464-494. doi:10.1086/318641.

Couper, Mick P., Arie Kapteyn, Matthias Schonlau, and Joachim Winter. 2007. 'Noncoverage and Nonresponse in an Internet Survey'. Social Science Research 36 (1): 131-148. doi:10.1016/j.ssresearch.2005.10.002.

Cutts, Beth, Tristram Hooley, and Julia Yates. 2015. 'Graduate Dress Code: How Undergraduates Are Planning to Use Hair, Clothes and Make-up to Smooth Their Transition to the Workplace'. Industry and Higher Education 29 (4): 271282. doi:10.5367/ihe.2015.0261.

Dacre Pool, Lorraine, and Pamela Qualter. 2012. 'Improving Emotional Intelligence and Emotional Self-Efficacy through a Teaching Intervention for University Students'. Learning and Individual Differences 22 (3): 306-312. doi:10.1016/j.lindif.2012.01.010.

Dillman, Don A. 2007. Mail and Internet Surveys: With New Internet, Visual, and Mixed-Mode Guide: The Tailored Design Method. 2nd Edition edition. Hoboken, N.J: John Wiley \& Sons.

Eriksson, Stefan, Per Johansson, and Sophie Langenskiöld. 2017. "What 2Is the Right Profile for Getting a Job? A Stated Choice Experiment of the Recruitment Process.” Empirical Economics 53 (2): 803-826. doi:10.1007/s00181-016-11331.

Fan, Weimiao, and Zheng Yan. 2010. 'Factors Affecting Response Rates of the Web Survey: A Systematic Review'. Computers in Human Behavior 26 (2): 132-139. doi:10.1016/j.chb.2009.10.015.

Frankham, Jo. 2017. "Employability and Higher Education: The Follies of the 'Productivity Challenge' in the Teaching Excellence Framework.” Journal of Education Policy 32 (5): 628-641. doi:10.1080/02680939.2016.1268271.

Gil, Natalie. 2014. "One in seven students work full-time while they study." The Guardian, 11 August 2014. https://www.theguardian.com/education/2014/aug/11/students-work-part-timeemployability (accessed 15 June 2018).

Groves, Robert M., Robert B. Cialdini, and Mick P. Couper. 1992. 'Understanding the Decision to Participate in a Survey'. Public Opinion Quarterly 56 (4): 475-495. doi: $10.1086 / 269338$. 
Groves, Robert M. 2006. 'Nonresponse Rates and Nonresponse Bias in Household Surveys'. Public Opinion Quarterly 70 (5): 646-675. doi:10.1093/poq/nfl033.

HESA (2016) "Destinations of Leavers from Higher Education in the United Kingdom for the academic year 2014/15." Accessed 15 June 2018. https://www.hesa.ac.uk/news/30-06-2016/sfr237-destinations-of-leavers.

HESA (2017) "Destinations of Leavers from Higher Education in the United Kingdom for the academic year 2015/16." Accessed 15 June 2018. https://www.hesa.ac.uk/news/29-06-2017/sfr245-destinations-of-leavers.

Hinchliffe, Geoffrey William, and Adrienne Jolly. 2011. "Graduate Identity and Employability.” British Educational Research Journal 37 (4): 563-584. doi:10.1080/01411926.2010.482200.

Holmes, Len. 2001. 'Reconsidering Graduate Employability: The 'graduate Identity' Approach." Quality in Higher Education 7 (2): 111-119. doi:10.1080/13538320120060006.

Holmes, Leonard. 2013. “Competing Perspectives on Graduate Employability: Possession, Position or Process?" Studies in Higher Education 38 (4): 538-554. doi:10.1080/03075079.2011.587140.

Humburg, Martin, and Rolf van der Velden. 2015. "Skills and the Graduate Recruitment Process: Evidence from Two Discrete Choice Experiments." Economics of Education Review 49 (December): 24-41. doi:10.1016/j.econedurev.2015.07.001.

Jackson, Denise. 2014. "Factors Influencing Job Attainment in Recent Bachelor Graduates: Evidence from Australia.” Higher Education 68 (1): 135-153. Jackson, Denise. 2016. "Skill Mastery and the Formation of Graduate Identity in Bachelor Graduates: Evidence from Australia.” Studies in Higher Education 41 (7): 1313-1332. doi:10.1080/03075079.2014.981515.

Jones, Elspeth. 2013. 'Internationalization and Employability: The Role of Intercultural Experiences in the Development of Transferable Skills'. Public Money \& Management 33 (2): 95-104. doi:10.1080/09540962.2013.763416.

Kinash, Shelley, Linda Crane, Madelaine-Marie Judd, and Cecily Knight. 2016. "Discrepant Stakeholder Perspectives on Graduate Employability Strategies." Higher Education Research \& Development 35 (5): 951-967. doi:10.1080/07294360.2016.1139555. 
Kucel, Aleksander, Péter Róbert, Màrian Buil, and Núria Masferrer. 2016.

'Entrepreneurial Skills and Education-Job Matching of Higher Education Graduates'. European Journal of Education 51 (1): 73-89. doi:10.1111/ejed.12161.

Lin, Yi-chun. 2015. 'Are You a Protean Talent? The Influence of Protean Career Attitude, Learning-Goal Orientation and Perceived Internal and External Employability'. Career Development International 20 (7): 753-772. doi:10.1108/CDI-04-2015-0056.

Manfreda, Katja Lozar, Michael Bosnjak, Jernej Berzelak, Iris Haas, and Vasja Vehovar. 2008. 'Web Surveys versus Other Survey Modes: A Meta-Analysis Comparing Response Rates'. International Journal of Market Research 50 (1): 79-104.

Marsh, David. 2008. "Understanding British Government: Analysing Competing Models." British Journal of Politics and International Relations, 10 (2): 251-268.

Marsh, David, David Richards, Martin Smith. 2003. "Unequal Plurality: Towards an Asymmetric Power Model of British Politics." Government and Opposition, 38 (3): 306-332.

Meterko, Mark, Joseph D. Restuccia, Kelly Stolzmann, David Mohr, Caitlin Brennan, Justin Glasgow, and Peter Kaboli. 2015. 'Response Rates, Nonresponse Bias, and Data Quality: Results from a National Survey of Senior Healthcare Leaders'. Public Opinion Quarterly 79 (1): 130-144. doi:10.1093/poq/nfu052.

ONS (2018) 'Understanding the gender pay gap in the UK,' no date, https://www.ons.gov.uk/employmentandlabourmarket/peopleinwork/earningsan dworkinghours/articles/understandingthegenderpaygapintheuk/2018-01-17 (accessed 15 June 2018).

Okay-Somerville, Belgin, and Dora Scholarios. 2017. "Position, Possession or Process? Understanding Objective and Subjective Employability during University-toWork Transitions." Studies in Higher Education 42 (7): 1275-1291. doi:10.1080/03075079.2015.1091813.

Orrell, J. 2004. "Work-Integrated Learning Programmes: Management and Educational Quality.” In. Proceedings of the Australian Universities Quality Forum, Victoria, Victoria University. Victoria: Victoria University, pp. 76-80.

Qenani, Eivis, Neal MacDougall, and Carol Sexton. 2014. 'An Empirical Study of SelfPerceived Employability: Improving the Prospects for Student Employment 
Success in an Uncertain Environment'. Active Learning in Higher Education 15 (3): 199-213. doi:10.1177/1469787414544875.

Richardson, John. 2015. “Academic Attainment in Students with Dyslexia in Distance Education.” Dyslexia 21: 323-337.

Savage, Mike, Fiona Devine, Niall Cunningham, Mark Taylor, Yaojun Li, Johs

Hjellbrekke, Brigitte Le Roux, Sam Friedman, and Andrew Miles. 2013. 'A

New Model of Social Class? Findings from the BBC's Great British

Class $\quad$ Survey Experiment'. Sociology 47 (2): 219-250.

doi:10.1177/0038038513481128.

Sheehan, Kim Bartel. 2002. 'Toward a Typology of Internet Users and Online Privacy Concerns'. The Information Society 18 (1): 21-32.

doi: $10.1080 / 01972240252818207$.

Social Watch. 2012. "Gender Equality Index by Country.” Accessed 19 June 2018. http://www.socialwatch.org/node/14367.

Teijeiro, Mercedes, Paolo Rungo, and Mª Jesús Freire. 2013. “Graduate Competencies and Employability: The Impact of Matching Firms' Needs and Personal Attainments.” Economics of Education Review 34 (June): 286-295. doi:10.1016/j.econedurev.2013.01.003.

Tomlinson, Michael. 2012. "Graduate Employability: A Review of Conceptual and Empirical Themes." Higher Education Policy 25: 407-431.

Weiss, Felix, Markus Klein, and Thomas Grauenhorst. 2014. 'The Effects of Work Experience during Higher Education on Labour Market Entry: Learning by Doing or an Entry Ticket?' Work, Employment and Society 28 (5): 788-807. doi:10.1177/0950017013506772.

Wilton, Nick. 2011. "Do Employability Skills Really Matter in the UK Graduate Labour Market? The Case of Business and Management Graduates.” Work, Employment and Society 25 (1): 85-100. doi:10.1177/0950017010389244.

Wilton, Nick. 2012. "The Impact of Work Placements on Skills Development and Career Outcomes for Business and Management Graduates.” Studies in Higher Education 37 (5): 603-620. doi:10.1080/03075079.2010.532548.

Wright, Toni, and Gill Frigerio. 2015. Career Adapt-Abilities Pilot Project. York: HEA. Yammarino, Francis J., Steven J. Skinner, and Terry L. Childers. 1991. 'Understanding Mail Survey Response Behavior a Meta-Analysis'. Public Opinion Quarterly 55 (4): 613-639. doi:10.1086/269284. 
Table 1. Net experimental effects of graduate characteristics (percentages).

\begin{tabular}{lllll}
\hline Characteristic & $\begin{array}{l}\text { Initial A }(\mathrm{N}= \\
17)\end{array}$ & $\begin{array}{l}\text { Initial } \\
\mathrm{B}\end{array}$ & $\begin{array}{l}\text { Swing to } \mathrm{B}(\mathrm{N}= \\
17)\end{array}$ & $\begin{array}{l}\text { Swing to C }(\mathrm{N} \\
=19)\end{array}$ \\
\hline Gender & 70.6 & 29.4 & $+15.2^{* *}$ & \\
Age & 67.2 & 32.8 & $+43.7^{* *}$ & \\
Disability & 82.4 & 17.6 & $+26.0^{* *}$ & \\
Ethnicity & 17.6 & 82.4 & $-17.7^{* *}$ & -8.7 \\
Work placement & 35.3 & 64.7 & $+17.7^{* *}$ & $-17.3^{* *}$ \\
Study abroad & 58.8 & 41.2 & $+23.5^{* *}$ & $-14.9^{* *}$ \\
Extra-curricular & 69.2 & 30.8 & $+16.3^{* *}$ & \\
activities & & & & +8.1 \\
Degree type & 76.5 & 23.5 & $+35.3^{* *}$ & $+14.9^{* *}$ \\
Degree class & 38.4 & 61.6 & + & \\
\hline
\end{tabular}

**Difference significant at the 0.01 level chi square test; *difference significant at the 0.05 level chi square test. 


\section{Appendix}

These are the candidate biographies used in the survey experiment. Alterations in candidate biographies are indicated using italics. Where possible, the treatment took the form of a different candidate photograph with no alterations to the text.

\begin{tabular}{|c|c|c|c|}
\hline $\begin{array}{l}\text { Test } \\
\text { characteristic }\end{array}$ & Original & First alteration & Second alteration \\
\hline Sex & $\begin{array}{l}\text { My name is Saina Nehwal. } \\
\text { I'm } 21 \text { and from Plymouth. } \\
\text { I'll graduate this summer } \\
\text { with a BA in Politics. I } \\
\text { think I'm employable } \\
\text { because my degree has } \\
\text { given me good research } \\
\text { skills and the ability to } \\
\text { articulate myself orally and } \\
\text { in writing, and because I } \\
\text { have quite a bit of work } \\
\text { experience. I've worked in a } \\
\text { coffee shop in the Student's } \\
\text { Guild for the past two years } \\
\text { while at university, and } \\
\text { done lots of casual work } \\
\text { during the summer holidays. } \\
\text { My name is Jack Jones. I'm } \\
22 \text { years old and originally } \\
\text { from Leeds. I'm doing a BA } \\
\text { in International Relations. I } \\
\text { think I'm employable } \\
\text { because I'm on course to get } \\
\text { a } 2.1 \text {, and because I'm active } \\
\text { in the Student's Guild. I'm } \\
\text { proud to have helped found } \\
\text { the Students' Action for } \\
\text { Refugees (STAR) Society in } \\
\text { my second year at } \\
\text { university, which I think } \\
\text { shows good organisational } \\
\text { and teamworking skills. }\end{array}$ & $\begin{array}{l}\text { My name is Saina Nehwal. } \\
\text { I'm } 21 \text { and from Plymouth. } \\
\text { I'll graduate this summer } \\
\text { with a BA in Politics. I } \\
\text { think I'm employable } \\
\text { because my degree has } \\
\text { given me good research } \\
\text { skills and the ability to } \\
\text { articulate myself orally and } \\
\text { in writing, and because I } \\
\text { have quite a bit of work } \\
\text { experience. I've worked in a } \\
\text { coffee shop in the Student's } \\
\text { Guild for the past two years } \\
\text { while at university, and } \\
\text { done lots of casual work } \\
\text { during the summer holidays. } \\
\text { My name is Gemma Jones. } \\
\text { I'm } 22 \text { years old and } \\
\text { originally from Leeds. I'm } \\
\text { doing a BA in International } \\
\text { Relations. I think I'm } \\
\text { employable because I'm on } \\
\text { course to get a } 2.1 \text {, and } \\
\text { because I'm active in the } \\
\text { Student's Guild. I'm proud } \\
\text { to have helped found the } \\
\text { Students' Action for } \\
\text { Refugees (STAR) Society in } \\
\text { my second year at } \\
\text { university, which I think } \\
\text { shows good organisational } \\
\text { and teamworking skills. }\end{array}$ & No second alteration. \\
\hline Age & $\begin{array}{l}\text { I'm Amelia Boivin. I'm } 21 \\
\text { years old and from } \\
\text { Newcastle. My degree is a } \\
\text { BA in Politics and } \\
\text { Sociology. I think I'm a } \\
\text { pretty well-rounded } \\
\text { individual, in terms of my } \\
\text { employability. I've done } \\
\text { well on most of my modules } \\
\text { and I'm involved in lots of }\end{array}$ & $\begin{array}{l}\text { I'm Amelia Boivin. I'm } 21 \\
\text { years old and from } \\
\text { Newcastle. My degree is a } \\
\text { BA in Politics and } \\
\text { Sociology. I think I'm a } \\
\text { pretty well-rounded } \\
\text { individual, in terms of my } \\
\text { employability. I've done } \\
\text { well on most of my modules } \\
\text { and I'm involved in lots of }\end{array}$ & No second alteration \\
\hline
\end{tabular}


extra-curricular activities.

I'm a member of the women's netball 1 st team and have done some committee work in the Friends of Israel Society. I also have good language skills, having studied French at A-Level and Arabic at the University's Foreign Language Centre.

My name is Olivia Brown. I'm 42 and from London.

I'm returning to education after having worked fulltime for several years. I chose to study Philosophy and Politics because of the way the two subjects complement each other. I think philosophy provides answers to the 'big' questions and helps develop critical thinking skills, while politics allows you to apply these to real-world issues. In my time at Exeter I've represented my fellow students as an elected member of the Staff Student Liaison Committee.

Disablement

My name is Oliver Smith. I'm 21 years old and from Birmingham. Last summer I went to an 'eXfactor' event put on by the Career Zone, which was all about identifying what I needed to do, to be able to compete in the graduate jobs market. Coming out of this one of my priorities was to gain some relevant work experience, so I picked the 'Learning from Work Experience in Social Sciences' module in my third year, which included a two month work placement.

My name is Emily Williams. I'm 21 years old. I grew up in Exeter, so knew extra-curricular activities.

I'm a member of the women's netball 1 st team and have done some committee work in the Friends of Israel Society. I also have good language skills, having studied French at A-Level and Arabic at the University's Foreign Language Centre.

My name is Olivia Brown. I'm 21 and from London. I decided to study Philosophy and Politics because of the way the two subjects complement each other. I think philosophy provides answers to the 'big' questions and helps develop critical thinking skills, while politics allows you to apply these to real-world issues. In my time at Exeter I've represented my fellow students as an elected member of the Staff Student Liaison Committee.

Altered with photograph:
No second alteration

\section{female}


quite a bit about the

University and its reputation

because of friends and

family who had been here. I

think what makes me

employable is that I'm

hopefully going to graduate

with a good degree, and I've

gained lots of skills that are

going to help me in the

workplace due to having

quite an important job in the

Student's Guild as Disabled

Students' Officer.

Work placement

My name is Ioana Rusu. I'm 22 and originally from
Romania. The reason why I think I am employable is because I will be graduating this summer with a degree (BA Politics and Sociology) from a prestigious Russell Group university, I speak several languages

(Romanian, English,

Hungarian and some

French), and have significant work experience (I've worked part-time throughout my studies at a restaurant in Exeter).

I'm Thomas Wright. I'm 22 and from Sheffield. I'm doing a BA in Politics with Study Abroad. I think it's made me more employable because spending a year at the Universidad Rey Juan Carlos in Madrid really improved my Spanish, and the modules on my course were designed in collaboration with employers, so the assessment methods are a bit different and more in keeping with the real world of work.
My name is Ioana Rusu. I'm 22 and originally from Romania. The reason why I think I am employable is because I will be graduating this summer with a degree (BA Politics and Sociology) from a prestigious Russell Group university, I speak several languages

(Romanian, English, Hungarian and some French), and have significant work experience (I've worked part-time throughout my studies at a restaurant in Exeter).

I'm Thomas Wright. I'm 22 and from Sheffield. I'm doing a BA in Politics with Study Abroad. I think it's made me more employable because spending a year at the Universidad Rey Juan Carlos in Madrid really improved my Spanish, and the modules on my course were designed in collaboration with employers, so the assessment methods are a bit different and more in keeping with the real world of work. I think I particularly benefited from the 'Learning from Work Experience in Social Sciences' module I did in my second year that included a
My name is Ioana Rusu. I'm 22 and originally from Romania. The reason why I think I am employable is because I will be graduating this summer with a degree (BA Politics and Sociology) from a prestigious Russell Group university, I speak several languages (Romanian, English, Hungarian and some French), and have significant work experience (I've worked part-time throughout my studies at a restaurant in Exeter).

I'm Thomas Wright. I'm 22 and from Sheffield. I'm doing a BA in Politics with Study Abroad. I think it's made me more employable because spending a year at the Universidad Rey Juan Carlos in Madrid really improved my Spanish, and the modules on my course were designed in collaboration with employers, so the assessment methods are a bit different and more in keeping with the real world of work. I think the fact that I also worked part-time throughout my degree also helped in this respect. 
70 hour work placement in a role closely related to my degree.

Ethnicity $\quad$ My name is Anna Nowak. I'm 23 and originally from

Poland, but Exeter has been my home for the past five years. I think my degree (a BA in Politics with Study Abroad) makes me employable because it's helped me further develop my language skills (I speak three languages fluently), and because of Exeter's reputation for academic excellence, being one of just a handful of UK universities ranked in the top 100 worldwide.

My name is Mia Jackson.

I'm 24 and from

Birmingham. The main thing I've done to become more employable is achieving an Exeter Award, based on my volunteering (I was part of the Freshers Welcome Team in my second and third years), the skills training I've attended at the Career Zone, and the experience I gained settingup a small business offering proofreading services to international students.

\section{Degree type My name is Georgia} Johnson. I'm 23 years old and originally from Liverpool. Something about my course that I think has improved my employability was the ability to tailor my degree by choosing several modules from other disciplines. I did a statistics module in the Mathematics department and macroeconomics module in
Altered with photograph: young black female.

.

Altered with photograph: young Asian female.

My name is Anna Nowak. I'm 23 and originally from Poland, but Exeter has been my home for the past five years. I think my degree (a BA in Politics with Study Abroad) makes me employable because it's helped me further develop my language skills (I speak three languages fluently), and because of Exeter's reputation for academic excellence, being one of just a handful of UK universities ranked in the top 100 worldwide.

My name is Farhat Hashmi. I'm 24 and from Birmingham. The main thing I've done to become more employable is achieving an Exeter Award, based on my volunteering (I was part of the Freshers Welcome Team in my second and third years), the skills training I've attended at the Career Zone, and the experience I gained settingup a small business offering proofreading services to international students.

My name is Georgia

Johnson. I'm 23 years old and originally from Liverpool. Something about my course that I think has improved my employability was the ability to tailor my degree by choosing several modules from other disciplines. I did a statistics module in the Mathematics department and macroeconomics module in
My name is Georgia Johnson. I'm 23 years old and originally from Liverpool. Something about my course that I think has improved my employability was the ability to tailor my degree by choosing several modules from other disciplines. I did a statistics module in the Mathematics department and macroeconomics module in 
the Business School, which I think makes me more well rounded than most graduates with a BA in Politics.

I'm Charlie Davies. I'm 21 years old and from London. 'Employability' is something they really emphasise on my degree (a BA in International Relations), so besides putting a lot of effort into the academic side of things (I'm hopefully going to graduate with a first), I've also tried to do some worthwhile extracurricular activities. The one I've enjoyed the most has been the Grand Challenges event, which was a multiday event that explored ways of making a success of Brexit.

Degree classification
My name is Isla Thompson. I'm 21 and from Stoke. I graduated with an Upper Second in International Relations. I worked in the Students' Guild bar during my last two years at University, and at a pub closer to home each summer. I was also quite heavily involved in extracurricular activities, as a member of the Out of Doors Society. I even became President at the start my final year, helping to organise walks to different places throughout the UK.

My name is Annalise Evans. I'm 24 years old and from Dartmouth. I graduated with a First in Politics. I focused a lot on employability while I was studying. I took part in the Sprint Personal Development Programme, which is all about helping female students succeed the Business School, which

I think makes me more well rounded than most graduates with a BA in Politics.

I'm Charlie Davies. I'm 22 years old and from London. Employability is something they really emphasise on my degree (an $M A$ in International Relations), so besides putting a lot of effort into the academic side of things (I'm hopefully going to graduate with a distinction), I've also tried to do some worthwhile extracurricular activities. The one I've enjoyed the most has been the Grand Challenges event, which was a multiday event that explored ways of making a success of Brexit.

My name is Isla Thompson. No second alteration. I'm 21 and from Stoke. I graduated with an Upper Second in International Relations. I worked in the Students' Guild bar during my last two years at University, and at a pub closer to home each summer. I was also quite heavily involved in extracurricular activities, as a member of the Out of Doors Society. I even became President at the start my final year, helping to organise walks to different places throughout the UK.

My name is Annalise Evans. I'm 24 years old and from Dartmouth. I graduated with an Upper Second in Politics. I focused a lot on employability while I was studying. I took part in the Sprint Personal Development Programme, which is all about helping

the Business School, which I think makes me more well rounded than most graduates with a BA in Politics.

I'm Charlie Davies. I'm 26 want to work in higher education, so I've tried to think more about got to graduation. An adviser I spoke to in the Career Zone recommended adding some extracurricular activities to my $C V$, so I took part in the Exeter Grand Challenges event this summer, which was a multi-day event that explored ways of making a success of Brexit.

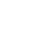

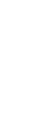
years old and from London.

I'm doing a PhD, but I don't employability the closer I've 
through specialised skills training and building useful contacts. I also worked parttime throughout my degree, and took part in various extra-curricular activities, such as regular Debate Society events.

Study abroad

My name is Catria White.

I'm 22 and from London.

I'm doing a BA in

International Relations. In

terms of my employability, the thing I'm most proud of is having last year won a Santander Universities scholarship to attend the University of California, Berkeley Summer Session in social sciences. This is a highly competitive scholarship worth $£ 4000$. I'm also an avid member of the Politics Society, helping to run its regular guest speaker events.

My name is Dulip Mendis. I'm 23 and from Manchester. My degree is an MA in European Politics. The main thing I've done, employability-wise, is complete my Higher Education Achievement Report (HEAR), which leads to a University-issued record of my academic work, extra-curricular activities, awards, and work experience. The most notable thing in my HEAR is probably taking part in the Students as Change Agents scheme and coming up with an idea to make module feedback from previous years available to students choosing their modules. female students succeed through specialised skills training and building useful contacts. I also worked parttime throughout my degree, and took part in various extra-curricular activities, such as regular Debate Society events.

My name is Catria White. I'm 22 and from London. I'm doing a BA in

International Relations. In terms of my employability, the thing I'm most proud of is having last year won a Santander Universities scholarship to attend the University of California, Berkeley Summer Session in social sciences. This is a highly competitive scholarship worth $£ 4000$.

I'm also an avid member of the Politics Society, helping to run its regular guest speaker events.

My name is Dulip Mendis. I'm 23 and from

Manchester. My degree is an MA in European Politics with Study Abroad at Université de Strasbourg, which I think has made me more employable because it helped me develop my

French speaking skills. The other main thing I've done, employability-wise, is complete my Higher Education Achievement Report (HEAR), which leads to a University-issued record of my academic work, extra-curricular activities, awards, and work experience. The most notable thing in my HEAR is probably taking part in the Students as Change Agents scheme and coming up with an idea to make module feedback from
My name is Catria White. I'm 22 and from London. I'm doing a BA in International Relations. In terms of my employability, the thing I'm most proud of is having last year won a Santander Universities scholarship to attend the University of California, Berkeley Summer Session in social sciences. This is a highly competitive scholarship worth $£ 4000$. I'm also an avid member of the Politics Society, helping to run its regular guest speaker events.

My name is Dulip Mendis. I'm 23 and from Manchester. My degree is an MA in European Politics with Study Abroad at Colorado State University in the United States, which I think has made me more employable because it exposed me to a wider variety of cultures and ways of thinking. The other main thing I've done, employability-wise, is complete my Higher Education Achievement Report (HEAR), which leads to a University-issued record of my academic work, extra-curricular activities, awards, and work experience. The most notable thing in my HEAR is probably taking part in the Students as Change Agents scheme and coming 
previous years available to students choosing their modules.

Extracurricular activities

My name is Ines Lefebvre. I'm 24 and from Lyon. Employability is really I'm 24 and from Lyon. Employability is really important to me because I want to work in the UK after graduation. The advice the Career Zone gave me was to build up my workrelated skills, so I chose modules such as 'Data Analysis in the Workplace', that had a more applied focus. I also did a four week work placement last summer with Lloyds Banking Group, and managed to become the Subject Chair for Politics, representing students' voices to the department.

I'm James Green. I'm 22 and originally from Oxford. I feel as though I have become much more employable because of my degree. I'm doing a BA in Politics with a year abroad at Humboldt Universitat in Berlin as an Erasmus+ student. This has really helped develop my fluency in German, not to mention my general academic skills, such as critical thinking and oral and written expression. While in Exeter, I've also tried to get involved in the extra-curricular side of things, being an avid member of, and helping to run the Guild's student-run radio station, XpressionFM. up with an idea to make module feedback from previous years available to students choosing their modules.

My name is Ines Lefebvre. No second alteration. important to me because I want to work in the UK after graduation. The advice the Career Zone gave me was to build up my workrelated skills, so I chose modules such as 'Data Analysis in the Workplace', that had a more applied focus. I also did a four week work placement last summer with Lloyds Banking Group, and managed to become the Subject Chair for Politics, representing students' voices to the department.

I'm James Green. I'm 22 and originally from Oxford. I feel as though I have become much more employable because of my degree. I'm doing a BA in Politics with a year abroad at Humboldt Universitat in Berlin as an Erasmus+ student. This has really helped develop my fluency in German, not to mention my general academic skills, such as critical thinking, and oral and written expression. 